\title{
REVIEW
}

\section{Multiple Endocrine Regulation by Bone Morphogenetic Protein System}

\author{
FUMIO OTSUKA \\ Endocrine Center of Okayama University Hospital; Department of Medicine and Clinical Science; Okayama University Graduate \\ School of Medicine, Dentistry and Pharmaceutical Sciences, Okayama 700-8558, Japan
}

\begin{abstract}
Bone morphogenetic proteins (BMPs) were originally identified with regard to their actions to regulate ectopic formation of bone and cartilage and early embryonic development. Subsequently, our research program has investigated a BMP system that exists in the mammalian ovary and plays roles in regulating numerous granulosa cell functions. BMP ligands including BMP-2, $-4,-6,-7$ and -15 were found to inhibit gondotropin-dependent progesterone synthesis by granulosa cells, which led to the hypothesis that BMPs are a physiological luteinization inhibitor in growing ovarian follicles during the follicular phase of the ovarian cycle. The physiological importance of the BMP system for normal mammalian reproduction has been further recognized by the discovery of aberrant reproductive phenotypes of female sheep and humans having mutated genes encoding BMP-15. Physiological roles of BMPs in the pituitary, hypothalamus, adrenal and other tissues have also been discovered. Here we discuss recent advances in the understanding of autocrine/paracrine actions of BMPs in the systemic regulation of endocrine function.
\end{abstract}

Key words: Bone morphogenetic protein, Folliculogenesis, Ovary, Reproduction, Steroidogenesis

BONE MORPHOGENETIC PROTEINS (BMPs) were originally isolated from bone tissues as proteins that induce bone and cartilage formation in ectopic extra-skeletal sites in vivo [1]. The amino acid sequences from the corresponding cDNAs revealed that BMP ligands are structurally classified into transforming growth factor (TGF)- $\beta$ superfamily member. To date, more than 30 members of the TGF- $\beta$ superfamily have been identified in various species $[2,3]$. There is no direct evidence that all molecules designated as BMPs can induce cartilage and/or bone formation, whereas it has been well established that BMPs regulate multiple biological processes including cell proliferation, apoptosis, differentiation and morphogenesis. In this review, the recent advances regarding critical BMP actions in the ovarian folliculogenesis, which has been mostly dis-

Received Oct. 19, 2009; Accepted Oct. 20, 2009 as K09E-310 Released online in J-STAGE as advance publication Oct. 30, 2009 Correspondence to: Fumio OTSUKA, M.D., Ph.D., Endocrine Center of Okayama University Hospital, 2-5-1 Shikata-cho, Kitaku, Okayama city, 700-8558, Japan. E-mail: fumiotsu@md.okayama-u.ac.jp Abbreviations: AC, adenylate cyclase; ActRI and ActRII, activin type I and type II receptor; ALK, activin receptor-like kinase; BMP, bone morphogenetic protein; BMPRI and BMPRII, BMP type I and covered by Shimasaki's laboratory $[4,5]$, and in many of extra-gonadal endocrine tissues are introduced.

\section{I) Molecular characteristics and receptor signaling of the BMP system}

Ligands of the TGF- $\beta$ superfamily are initially synthesized as large precursor proteins. The precursor proteins dimerize and then are cleaved by proteolytic processing to produce mature dimeric proteins. The BMPs are distinguished from other members by having seven, rather than nine, conserved cysteine residues in the mature region. Six of the seven common cysteines in the mature protein are linked within the subunit to form a rigid structure called a "cysteine knot." The re-

type II receptor; ER, estrogen receptor; ERK, extracellular signalregulated kinase; FSH, follicle-stimulating hormone; GDF, growth differentiation factor; GnRH, gonadotropin-releasing hormone; MAPK, mitogen-activated protein kinase; PKA, protein kinase A; P450arom, P450 aromatase; P450scc, P450 steroid side-chain cleavage enzyme; SAPK/JNK, stress-activated protein kinase / Jun-N-terminal kinase (JNK); StAR, steroidogenic acute regulatory protein; TGF- $\beta$, transforming growth factor- $\beta$ 
maining seventh cysteine is necessary for dimerization through disulphide bonding. BMP-15 and GDF-9 differ from other TGF- $\beta$ superfamily members in that their mature regions lack cysteine residue to be used for the intra-molecular S-S bonding [6, 7].

Seven type I (ALK-1, -2, -3, -4, -5, -6 and -7) and five type II (ActRII, ActRIIB, AMHR-II, BMPRII and T $\beta$ RII) receptors for TGF- $\beta$ superfamily members have been characterized in mammals. Both type I and type II receptors are structurally similar and possess serine/threonine kinase domains in their intracellular domains. Dimeric TGF- $\beta$ superfamily members bind to a heterotetrameric complex of two type I and two type II receptors. Type I receptors have "GS domain" in the transmembrane domain that is rich in glycine and serine residues. TGF- $\beta$ and activins first bind type II receptors and the type I receptors are subsequently recruited into a ligand-receptor complex. In the case of BMPs, both type II and type I receptors independently have certain affinity for the ligand and the complex can achieve high affinity binding [8].

Following binding of a BMP to its receptor, the phosphorylated type I receptors activate downstream signaling molecules Smads. The pathway-restricted Smads $(\operatorname{Smad} 1 / 5 / 8)$ are phosphorylated by type I receptors, and then they interact with a common-mediator Smad (Smad4) to form a hetero-oligomeric complex with Smad1/5/8. The complex then translocates to the nucleus, where it binds directly or indirectly to target DNA and induces transcription of specific genes [9]. Other signaling pathways also exist concurrently with Smad signaling such as TGF- $\beta$-activated kinase (TAK-1), a member of the mitogen-activated protein kinase kinase kinase (MAPKKK) family and members of the Ras or Rac families of small GTP-binding proteins. Extracellular signal-regulated kinase-1/2 (ERK1/2), and stress-activated protein kinase (SAPK)/ Jun-N-terminal kinase (JNK), have also been linked to TGF- $\beta$ signal transduction in some cell types.

\section{II) Roles of ovarian BMP system in female reproductive function}

Expression of BMP ligands and BMP receptors in the ovary

Expression of BMP-2, -3, -3b, -4, -6, -7, -15 and GDF-9, and BMP receptor type IA (BMPRIA/ALK-3), type IB (BMPRIB/ALK-6) and type II (BMPRII) were identified in the ovary of various mammals [10]. The various BMP ligands are expressed in cell-specific expression patterns in ovarian cells that undergo dynamic changes during follicular development and corpora luteal morphogenesis [5]. It is therefore possible that the developmental process of folliculogenesis (recruitment, selection and atresia), ovulation, and luteogenesis (luteinization and luteolysis) are accompanied by dramatic spatial and temporal changes in the expression patterns of these BMP genes.

\section{Ligand-dependent BMP actions in granulosa cell functions}

BMP-2, -4, -6 and -7 each exerts activities on ovarian steroidogensis and granulosa cell mitosis in the ovary. BMP-4 and BMP-7 are expressed in theca cells and regulate follicle-stimulating hormone (FSH)-induced estradiol and progesterone production by granulosa cells by increasing FSH-induced estradiol and suppressing progesterone production [4]. An in vivo study showed that BMP-7 decreases the number of primordial follicles but increases the number of primary, secondary and antral follicles [11]. Thus, BMP-7 promotes the "recruitment" of primordial follicles into the growing follicle pool, while inhibiting ovulation and progesterone production. Similar to BMP-4 and -7, BMP-6 inhibits FSH-induced progesterone synthesis by granulosa cells [12]. BMP-6 is expressed in the oocytes and granulosa cells of healthy Graafian follicles [10]. BMP-6 inhibits FSH actions by suppressing adenylate cyclase activity [12]. BMP-6 mRNA expression in granulosa but not oocytes rapidly decreases at the time when the dominant follicle is selected [10], implying that BMP-6 is linked to the mechanism of dominant follicle "selection". Unlike BMP-7 action, which induces granulosa cell proliferation, BMP-6 has no significant effect on granulosa cell mitosis. Interestingly, BMP-7 increases FSH-induced estradiol production whereas BMP-6 has no impact on estradiol synthesis [13]. BMP-7 action is in part mediated through a FSH receptor signaling that is independent of cAMP-PKA pathway, i.e. BMP-7 actions on FSH-induced estradiol production occur through suppression of ERK1/2 downstream of FSH receptor signaling [13]. Likewise, BMP-2 and -4 enhance FSH-induced p38-MAPK phosphorylation, leading to an increase of FSH-induced estradiol production [14]. Thus, BMP-2, -4, -6 and -7 differentially regulate $\mathrm{FSH}$-induced steroidogenesis by graunlosa 


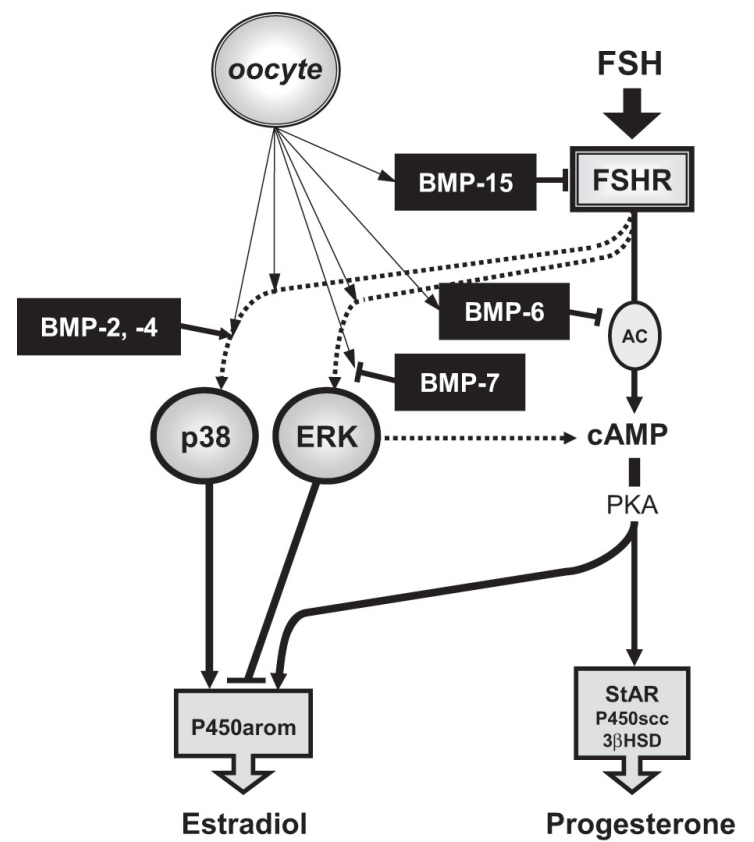

Fig. 1. BMP system regulates steroidogenesis through oocytegranulosa cell communication in the ovary.

FSH activates estradiol and progesterone production through cAMP-to-PKA pathway in graunlosa cells in the ovary. FSH simultaneously stimulates MAPKs, leading to the pathway-specific modulation of FSH-induced steroidogensis. For instance, BMP-15 inhibits FSH receptor expression while BMP-6 suppresses adenylate cyclase (AC) activity, both of which result in reduction of progesterone production. BMP-2 and -4 activate FSHinduced $\mathrm{p} 38$, leading to stimulation of estradiol production. BMP-7 inhibits FSH-induced ERK1/2 phosphorylation, leading to upregulation of estradiol production since ERK $1 / 2$ activation is directly linked to inhibition of estradiol. In addition to the regulation of steroidogenesis by granulosa cells, oocyte and/or oocyte-derived factors facilitate FSH-to-MAP kinase and BMP-to-Smad signaling activity, which supports effective control of FSH-induced steroidogenesis by granulosa cells.

cells in ligand-dependent mechanisms (Fig. 1).

Oocyte-derived BMP-15 inhibits FSH receptor expression and stimulates granulosa cell mitosis

Analysis by in situ hybridization and immunohistochemistry demonstrated BMP-15 expression exclusively in the oocyte, with its expression increasing in association with follicle growth and development [15]. BMP-15 inhibits FSH action by suppressing FSH receptor expression [16]. Specifically, FSH-induced expression of steroidogenic acute regulatory protein (StAR), P450 steroid side-chain cleavage enzyme (P450scc), 3 $\beta$-hydroxysteroid dehydrogenase (HSD), luteininzing hormone (LH) receptor and inhibin/activin subunits are all inhibited by BMP-15 [16]. The finding that $\mathrm{FSH}$-induced progesterone synthesis are inhibited by BMP-15 demonstrates that BMP-15, like BMP-4, $-6,-7$ and GDF-9, is part of a group of "luteinization inhibitors" [17]. BMP-15 also stimulates granulosa cell proliferation in a dose-dependent manner [15]. Moreover, BMP-15 stimulates the expression of kit ligand (KL) mRNA in granulosa cells [18].

Oocyte-derived BMP-15 and granulosa-derived KL form a novel negative feedback loop that is functionally linked to granulosa cell proliferation. BMP-15 also stimulates cumulus expansion [19], which is associated with the enhanced expression of epidermal growth factor-like growth factors in cumulus cells. These BMP15 actions are regulated by a binding protein follistatin [20]. Follistatin is strongly expressed in dominant follicles, but very low or undetectable in atretic follicles $[21,22]$. Because BMP-15 is an inhibitor of FSH receptor expression, it can be hypothesized that follistatin regulation of BMP-15 is important for normal folliculogenesis in vivo. Furthermore, BMP-Smad signal activities are also regulated by FSH receptor signaling, leading to fine-tuning of the mutual sensitivity of BMPs and FSH [23]. The "communication networks" between oocytes and follicular cells are crucial not only for the growth and maturation of the oocyte, but also for the proper differentiation of somatic follicular cells [24-26]. In this concept, oocyte-secreted factors play a key role in regulating FSH activity and FSH sensitivity during folliculogenesis (Fig. 1).

The significance of BMP-15 in reproductive endocrinology: lessons from sheep and human mutations

As shown above, all these BMPs have been found to be selective inhibitors of progesterone synthesis induced by FSH. This provides strong support for the hypothesis that BMPs are long sought "luteinization inhibitors".

The Inverdale strain of sheep have been have been found to carry a single point mutation in the "matureprotein" region of the bmp 15 gene [27]. The heterozygous Inverdale mutants exhibit increased ovulation rates resulting in increased twinning. In the heterozygotes, reduced levels of intact BMP-15 may cause higher levels of FSH receptors in granulosa cells, leading to more developing follicles and high expression levels of LH receptors. Accordingly, the sheep would 
exhibit precocious follicle maturation and increased ovulatory follicles at each cycle. On the contrary, homozygous Inverdale females are infertile due to arrested follicle development at the primary follicle stage. The lack of bioactive BMP-15 and its mitotic effects and KL-promoting effects on granulosa cells could account for the arrest of follicle development in the homozygotes [15]. Thus, the reproductive phenotype of Inverdale ewe provides in vivo data that support our in vitro findings on the role of BMP-15 in regulating follicular development and establishes the importance of this oocyte-secreted factor in mammalian reproduction.

BMP-15 signaling is mediated by binding first to ALK-6 and then recruiting BMPRII to the complex [29]. Another strain of sheep that are highly prolific, Booroola sheep, have been found to carry a mutation in the BMPRIB/ALK-6 receptor [30-32], which is a key receptor for BMP-15. Granulosa cells of Booroola are more responsive to FSH than normal granulosa including cAMP production although the FSH binding capacity is not changed [33]. Ovarian follicules of Booroola ewes produce more progesterone induced by FSH than those from wild-type ewes. The enhanced FSH responsiveness of the follicles from Booroola ewes could be explained by the impaired ALK-6 signaling triggered by endogenous BMP-6 and/or BMP-15 [17].

A point mutation in the $g d f 9$ gene $\left(\mathrm{FecG}^{\mathrm{H}}\right)$ has also been discovered in a different strain of sheepthat has a similar phenotype to the Inverdale sheep having a bmp15 mutation [34]. Interestingly, ewes that are compound heterozygotes for both BMP-15 and GDF-9 mutations have significantly higher ovulation rates than heterozygous carriers of a mutation in only one of the genes $[34,35]$. These findings provide evidence for intracellular interactions between BMP-15 and GDF-9 that have important consequences on the secretion of the mature proteins. The in vitro observation that these proteins are secreted as homo-dimers when expressed individually and can form hetero-dimers when co-expressed [36, 37] supports this concept [38].

In human, a point mutation in the bmp15 gene has been discovered in women with infertility due to hypergonadotropic ovarian failure [39]. Recombinant proteins with this mutation lack biological activity, and, importantly, have antagonistic effects toward the wild-type BMP-15 protein. More recent studies have also revealed several point mutations in the bmp 15 and $g d f 9$ genes, located at the "pro-protein regions" that are associated with premature ovarian failure [40-42].

Despite the many recent discoveries of the properties and actions of BMP-15 and GDF-9 in vitro and the identification of functional effects of BMP-15 and GDF-9 mutations and deletions in various mammals in vivo, much work remains to connect the in vivo and in vitro findings and develop a further understanding of the precise mechanisms by which the interaction of these two factors have such important impacts on female reproductive physiology.

Along these lines, it has recently been found that posttranslational phosphorylation of recombinant BMP-15 and GDF-9 is essential for bioactivity of BMP-15 and GDF-9, and that the dephosphorylated forms of BMP-15 and GDF-9 exhibit antagonistic activity toward not only their phosphorylated counterparts but also toward each other, as well as BMP-7 [43].

\section{III) Roles of the BMP system in the pituitary and hypothalamus}

\section{BMP-6, -7 and -15 regulate pituitary gonadotrope function}

Locally-produced BMPs play a critical role in the differentiation of the pituitary gonadotrope [44, 45]. During normal mouse pituitary development, BMP-4 is expressed in the ventral diencephalon, while BMP-2 and the BMP binding protein, chordin, are expressed in the ventral condensing mesenchyme. BMP ligands and receptors are expressed in the adult pituitary gland. Specifically, BMP-6, -7 and -15 mRNAs are expressed in the pituitary of mice $[18,46]$, GDF-9 mRNA in the pituitary of humans [47], BMP-15 and GDF-9 mRNAs in the pituitary of brushtail possums [48] and BMP-15 mRNA in the pituitary of sheep [27]. With regard to BMP receptors, BMPRII, ActRII, ALK-2 and ALK-3 mRNAs are expressed in mice pituitaries [18], ALK-6 mRNA in sheep pituitaries [30], and ActRII and ActRIIB mRNAs in rat pituitaries [49]. Of potential physiological importance are the findings that BMP-6, -7 and -15 can act directly on pituitary gonadotropes to regulate FSH synthesis and secretion.

\section{BMP-4 action is associated with pituitary tumorigenesis}

The pituitary BMP system also acts as a regulator of transformation and tumorigenesis of differentiated pituitary cells. Human gonadotropinomas have reduced 
expression of the activin/BMP binding protein, follistatin, as compared with non-functioning tumors [50]. In addition, PPAR $\gamma$ activation is functionally linked to the inhibition of BMP receptor signaling in gonadotorope L $\beta$ T2 cells [51]. It is interesting that BMP-4 is overexpressed in various lactotrope tumor models and human prolactinomas [52], with the molecular interaction between BMP-4, Smad4 and estrogen receptor (ER) involved in regulating prolactinpromoter activity [53]. We have reported that BMP-4 activates GH and cAMP synthesis induced by forskolin in mouse lactosomatotrope GH3 cells [54]. It is of note, in the presence of a high concentration of somatostatin analogue octreotide, the effects of a dopamine agonist bromocriptine that suppresses BMP4-Smad1/5/8 signaling are impaired. These findings explain, at least in part, the mechanism of clinical resistance of GH reduction to a combination therapy with octreotide and bromocriptine in a subset of acromegaly patients. Giacomini and colleagues have reported that pituitary-expressed BMP-4 inhibits corticotrope cell proliferation and ACTH production by corticotrope tumor cells, and that BMP-4 expression can be augmented by retinoic acid [55]. Thus, the pituitary BMP system is likely to act as a regulator not only for pituitary differentiation but also for the transformation of differentiated pituitary cells.

Hypothalamic BMP system and gonadotropin-releasing hormone $(\mathrm{GnRH})$ regulation

ActRII and ActRIIB mRNAs are expressed in the rat hypothalamus. These receptors are found in the areas for neuroendocrine regulation including the suprachiasmatic, supraoptic, paraventricular and arcuate nuclei [49]. GnRH synthesis and release are tightly regulated by gonadal steroids, which maintain control through a negative feedback system [56]. In females, estrogens act directly or indirectly on the GnRH neuronal network to modulate the final output of GnRH into the median eminence $[57,58]$. An immortalized GnRH-producing GT1-7 cell line is a valuable tool to study the biology of GnRH neurons because of the expression of functional ER $[59,60]$. The interaction between BMP receptors and ER is involved in controlling hypothalamic GnRH production and secretion in GT1-7 cells [61]. In this system, BMP-2 and BMP-4 repress ER-induced downregulation of GnRH transcription by attenuating ERMAPK signaling. BMP-6 and BMP-7, in turn, increase
GnRH transcription and secretion by stimulating the expression of R-type calcium channel.

\section{IV) Involvement of BMP system in other endocrine tissues}

\author{
BMP-6 effects on aldosterone induction in the adre- \\ nal cortex
}

Aldosterone production occurs in the adrenal glomerulosa, and is regulated primarily by angiotensin II (Ang II), potassium and, to a lesser degree, adrenocorticotropin $(\mathrm{ACTH})[62,63]$. In the presence of the aldosterone stimulators, steroidogenesis in the adrenal cortex is further governed by local autocrine and/or paracrine factors [64]. We have reported the presence of a functional BMP and activin system complete with ligands including BMP-6, activins and their receptors in a human adrenocortical cell line $[65,66]$. Further investigation demonstrated that BMP-6 increased Ang II-induced aldosterone production [67]. This BMP-6 action could be involved in the "aldosterone breakthrough" phenomenon. Aldosterone breakthrough is a phenomenon where circulating aldosterone concentrations increase above pretreated levels after long-term therapy with ACE inhibitors $[68,69]$ or an Ang II type 1 receptor antagonist (ARB) [70]. This phenomenon may lead to important clinical consequences since increased aldosterone in a high salt state may facilitate cardiovascular and renal damages in hypertensive patients [71, 72]. Involvement of various in vivo factors such as ACTH, electrolytes, endothelins and Ang II type 2 receptor actions $[70,73]$ have been proposed. We found that a long-term ARB treatment reverses the reduction of aldosterone synthesis by adrenocortical cells, i.e., "cellular aldosterone breakthrough" [74]. This in vitro breakthrough was clearly attenuated by neutralization of endogenous BMP-6 and ALK-2, suggesting that BMP-6 availability in the adrenal cortex in situ may be at least in part involved in the occurrence of cellular escape from aldosterone suppression under chronic treatment with ARB.

\section{BMP-4 actions in the adrenal medulla on cate- cholamine synthesis}

The adrenal cortex and medulla functionally interact with each other in a paracrine manner $[75$, 
76]. Endogenous glucocorticoids are known to induce catecholamine biosynthesis by stimulating catecholamine-synthesizing enzymes through the cortico-medullary portal system [77]. We previously reported the presence of the BMP system in the adrenal medulla and a functional crosstalk between glucocorticoid and BMP system in regulating catecholamine synthesis in adrenomedullar PC12 cells [78]. The key components of the BMP system are expressed throughout neural development [79]. For instance, BMP-4 and BMP-7 are expressed in the dorsal aorta and direct sympathetic neuronal differentiation into the adrenergic characteristics [80]. BMP-4 and BMP-7 induce a tyrosine hydroxylase (TH)immunoreactive adrenergic phenotype in cultures of avian neural crest cells [81, 82]. We also found that BMP-4 and BMP-7 induce catecholamine production in the presence of mineralocorticoid in adrenal medullar cells. Catecholamine biosynthesis in adrenomedullar cells occurs via MR through genomic action and partly through nongenomic action by Rho-SAPK/JNK signaling [83]. Given that the nongenomic pathway was activated by BMP-4, this adrenocortical-medullar interaction via MR and BMPs was hypothesized to be involved in catecholamine regulation [83].

BMP system in the thyroid suppresses TSH receptor signaling

Thyrotropin (TSH) is the principal regulator of thyrocyte growth and hormone production. TSH transduces its signaling through TSH receptors (TSH-R) resulting in stimulation of the cAMP and phospholipase C (PLC) pathways (84). In the presence of $\mathrm{TSH}$, a number of growth factors act as mediators of thyrocyte growth. For instance, insulin and insulinlike growth factor-1 (IGF-1) acting via the IGF-1 receptor promote follicular cell growth synergistically with TSH [85]. TGF- $\beta 1$, activin A and BMP-7 proteins are expressed in the follicular epithelium of porcine thyroid sections [86]. The phosphorylation of Smad 2 by TGF- $\beta 1$ and activin inhibited thyrocyte mitosis, TSH-R expression and TSH-stimulated cAMP responses [86]. BMP-2, $-4,-6$ and -7 also suppress DNA synthesis, TSH-induced cAMP production and TSH-induced IGF-1 mRNA in porcine thyrocytes [87]. These data suggest that the BMP system in thyrocytes is negative regulator of TSH function as well as thyrocyte mitosis. Considering that BMP-7 also exerts dose-dependent suppression of DNA synthesis in neoplastic thyroid epithelial cells [88], the thyroid BMP system is likely to play a role in the suppression of thyroid tumorigenesis.

\section{V) BMP functions in cardiovascular and renal tissues}

\section{Involvement of BMP-2 and -7 in the progression of pulmonary arterial hypertension}

Approximately six percent of the primary arterial hypertension (PAH) cases possess an autosomal dominant pattern of inheritance. Recent research has uncovered a genetic predisposition to familial PAH $[89,90]$. Studies involving the screening of the locus of the gene for PAH, mapped to chromosome 2q33 (PPH1) have unveiled mutations in the $b m p r 2$ gene encoding the bone morphogenetic protein type II receptor (BMPRII) in nine out of nineteen [91], or seven out of eight families [92]. Furthermore, the mutation in the bmpr 2 gene can be detected in at least a quarter of apparently sporadic PAH cases [93]. Hence, the identification of heterozygous germline mutations in the bmpr2 gene in familiar and sporadic cases of PAH has proven to be a crucial breakthrough in elucidating underlying pathogenesis of PAH [89]. Subsequent functional studies have provided compelling evidence that PAH cells harboring the bmpr 2 mutations exhibit aberrant function of BMPRII and disrupted BMP signaling [94, 95]. In addition, the interaction between BMP ligands and type I receptors is also critical for the pulmonary arterial smooth muscle cell mitosis in PAH [96]. However, given that almost half of PAH patients do not bear the bmpr2 mutation, the mechanism of pulmonary arterial smooth muscle cell mitogenesis in PAH lungs remains uncertain.

\section{BMP-4 and -7 ameliorate glomerular mesangial cell proliferation in the kidney}

Recent studies have provided evidence that BMPs, in particular BMP-7, play a key role in the pathogenesis of various renal diseases including early experimental diabetic [97] or obstructive [98] nephropathy. BMP-4 and BMP-7 have important roles in renal development than other members of the BMP family, each of which has unique effects on different parts of the developing kidney [99]. In experimental animal models 


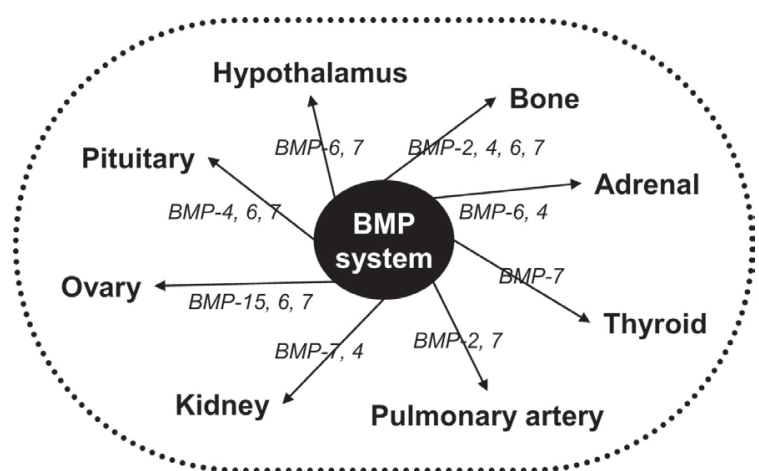

Fig. 2. The BMP system plays cell-specific roles in various endocrine tissues.

Recent data have demonstrated that BMPs are multifunctional regulators in various tissues and cells. In addition to bone, there is evidence that expression of BMP genes is high in the kidney, lung, small intestine, heart and that they can regulate the cellular homeostasis by autocrine/ paracrine mechanisms. A variety of physiological roles of BMPs in many endocrine tissues including ovary, adrenal, thyroid, pituitary and hypothalamus have been recently identified. The BMP system composed of BMP ligands, receptors and binding proteins is considered to be crucial regulator for fundamental endocrine functions. The dysregulation of BMP system in some specific tissues is also involved in the pathophysiology of various endocrine disorders.

of obstructive or diabetic nephropathy, BMP-7 reduces glomerular and tubulointerstitial fibrosis and preserves renal function [100, 101]. BMP-7 even resolves glomerular and interstitial fibrosis in rats with diabetic nephropathy [101], which results from inhibition of the TGF- $\beta$ effects on fibrosis mediators and matrix protein degrading enzymes [102]. BMP-7 antagonizes TGF- $\beta$ induced glomerular fibrogenesis and accumulation of collagen, fibronectin and thrombospondin in cultured mesangial cells, suggesting that BMP-7 opposes several profibrogenic activities of TGF- $\beta$ in mesangial cells [102]. BMP-4 and BMP-7 also antagonize aldosterone-induced mesangial cell proliferation by inhibiting MAPK activation as well as mineralocorticoid receptor (MR) expression [103]. Thus, BMP-4 and -7 seem to exert renoprotective actions leading to amelioration of glomerular sclerosis.

\section{BMP-6 and -7 inhibit breast cancer cell proliferation via estrogen receptor}

There has been accumulating evidence that breast cancer tissue expresses all enzymes required for the local biosynthesis of estrogen from circulating precur- sors, i.e. the aromatase pathway that transforms androgens into estrogens and the sulfatase pathway that converts estrone sulfate into estrone [104]. Therapeutic targets for breast cancers include not only the binding of estrogen to ER but also the activity of estrogenic enzymes in the tumor tissues [105]. There have been several reports showing the expression of some of TGF- $\beta$ superfamily proteins, such as BMP-2 [106], -6 [107], and -7 [108] in breast cancer cells, in which their possible role in breast cancer development and involvement in bone metastasis has been discussed $[109,110]$. Furthermore, the involvement of BMPSmad activation in the progression and dedifferentiation of ER-positive breast cancer was recently reported [111]. BMP-6 and -7 are also found to antagonize estrogen-induced breast cancer cell proliferation by inhibiting p38 phosphorylation and estrogenic enzyme expression [112]. The inhibitory effects of BMPs on the MAPK pathway and/or the expression of ER and estrogenic enzymes could be involved in the suppression of estrogen-induced mitosis of breast cancer cells.

\section{Conclusion}

Besides regulating bone formation and bone differentiation $[113,114]$, considerable recent data have demonstrated that BMPs are multifunctional regulators in a wide array of biological processes in both vertebrates and invertebrates [115]. In addition to bone, there is evidence that expression of BMP genes is high in the kidney (BMP-3, -4 and -7), lung (BMP-3, $-4,-5$ and -6 ), small intestine (BMP-3 and -7), heart (BMP-2, -4, -6 and -7), limb bud (BMP-2, -4, -5 and -7) and teeth (BMP-3, -4 and -7) and that they can regulate the cellular homeostasis by paracrine mechanisms [116]. A variety of BMP actions in many endocrine tissues including the ovary, pituitary, thyroid, adrenal and cardiovascular tissues has been gradually identified (Fig. 2). Especially, current research has demonstrated that the BMP system is a critical component of the local regulatory system in the ovary. Now we have recognized that BMP ligands and receptors are powerful regulators of fundamental endocrine functions. Accordingly, further research in this field will greatly advance our understanding of pathophysiology of systemic endocrine regulation and will lead to novel targets for wide-ranging clinical regimens aimed at controlling female reproduction, steroidogen- 
esis and endocrine tumorigenesis.

\section{Acknowledgements}

This context was presented in the $82^{\text {nd }}$ Japan Endocrine Society Meeting and Japan Endocrine
Society Research Award was awarded. I greatly appreciate Prof. Shunichi Shimasaki, University of California, San Diego, CA for supervising to my works and I also thank Dr. R. Kelly Moore for helpful discussion and critical reading of the manuscript. I also thank Drs. Tomoko Miyoshi, Kenichi Inagaki, Masaya Takeda and Jiro Suzuki for excellent experimental works.

\section{References}

1. Wozney JM, Rosen V, Celeste AJ, Mitsock LM, Whitters MJ, Kriz RW, Hewick RM, Wang EA (1988) Novel regulators of bone formation: Molecular clones and activities. Science 242:1528-1534.

2. Griffith DL, Keck PC, Sampath TK, Rueger DC, Carlson WD (1996) Three-dimensional structure of recombinant human osteogenic protein 1: structural paradigm for the transforming growth factor ß superfamily. Proc Natl Acad Sci U S A 93:878-883.

3. Kawabata M, Miyazono K (2000) Bone morphogenetic proteins. In: Canalis E ed. Skeletal Growth Factors. Philadelphia: Lippincott Williams \& Wilkins; 269-290.

4. Shimasaki S, Zachow RJ, Li D, Kim H, Iemura S, Ueno N, Sampath K, Chang RJ, Erickson GF (1999) A functional bone morphogenetic protein system in the ovary. Proc Natl Acad Sci U S A 96:7282-7287.

5. Shimasaki S, Moore RK, Otsuka F, Erickson GF (2004) The bone morphogenetic protein system in mammalian reproduction. Endocr Rev 25:72-101.

6. Dube JL, Wang P, Elvin J, Lyons KM, Celeste AJ, Matzuk MM (1998) The bone morphogenetic protein 15 gene is X-linked and expressed in oocytes. Mol Endocrinol 12:1809-1817.

7. McGrath SA, Esquela AF, Lee S-J (1995) Oocytespecific expression of growth/differentiation factor-9. Mol Endocrinol 9:131-136.

8. Liu F, Ventura F, Doody J, Massague J (1995) Human type II receptor for bone morphogenic proteins (BMPs): extension of the two-kinase receptor model to the BMPs. Mol Cell Biol 15:3479-3486.

9. Miyazono K, Kusanagi K, Inoue H (2001) Divergence and convergence of TGF-beta/BMP signaling. J Cell Physiol 187:265-276.

10. Erickson GF, Shimasaki S (2003) The spatiotemporal expression pattern of the bone morphogenetic protein family in rat ovary cell types during the estrous cycle. Reprod Biol Endocrinol 1:9.

11. Lee W, Otsuka F, Moore RK, Shimasaki S (2001) The effect of bone morphogenetic protein-7 on folliculogenesis and ovulation in the rat. Biol Reprod 65:994-999.

12. Otsuka F, Moore RK, Shimasaki S (2001) Biological function and cellular mechanism of bone morphogenetic protein-6 in the ovary. J Biol Chem 276:32889-
32895.

13. Miyoshi T, Otsuka F, Inagaki K, Otani H, Takeda M, Suzuki J, Goto J, Ogura T, Makino H (2007) Differential regulation of steroidogenesis by bone morphogenetic proteins in granulosa cells: involvement of extracellularly regulated kinase signaling and oocyte actions in follicle-stimulating hormone-induced estrogen production. Endocrinology 148:337-345.

14. Inagaki K, Otsuka F, Miyoshi T, Yamashita M, Takahashi M, Goto J, Suzuki J, Makino H (2009) p38Mitogen-activated protein kinase stimulated steroidogenesis in granulosa cell-oocyte cocultures: role of bone morphogenetic proteins 2 and 4. Endocrinology 150:1921-1930.

15. Otsuka F, Yao Z, Lee TH, Yamamoto S, Erickson GF, Shimasaki S (2000) Bone morphogenetic protein-15: Identification of target cells and biological functions. $J$ Biol Chem 275:39523-39528.

16. Otsuka F, Yamamoto S, Erickson GF, Shimasaki S (2001) Bone morphogenetic protein-15 inhibits folliclestimulating hormone (FSH) action by suppressing FSH receptor expression. J Biol Chem 276:11387-11392.

17. Shimasaki S, Moore RK, Erickson GF, Otsuka F (2003) The role of bone morphogenetic proteins in ovarian function. Reprod Suppl 61:323-337.

18. Otsuka F, Shimasaki S (2002) A novel function of bone morphogenetic protein-15 in the pituitary: selective synthesis and secretion of FSH by gonadotropes. Endocrinology 143:4938-4941.

19. Yoshino O, McMahon HE, Sharma S, Shimasaki S (2006) A unique preovulatory expression pattern plays a key role in the physiological functions of BMP-15 in the mouse. Proc Natl Acad Sci U S A 103:1067810683.

20. Otsuka F, Moore RK, Iemura S-I, Ueno N, Shimasaki S (2001) Follistatin inhibits the function of the oocytederived factor BMP-15. Biochem Biophys Res Commun 289:961-966.

21. Shimasaki S, Koga M, Buscaglia ML, Simmons DM, Bicsak TA, Ling N (1989) Follistatin gene expression in the ovary and extragonadal tissues. Mol Endocrinol 3:651-659.

22. Nakatani A, Shimasaki S, DePaolo LV, Erickson GF, 
Ling N (1991) Cyclic changes in follistatin gene expression and translation in the rat ovary during the estrous cycle. Endocrinology 129:603-611.

23. Miyoshi T, Otsuka F, Suzuki J, Takeda M, Inagaki K, Kano Y, Otani H, Mimura Y, Ogura T, Makino H (2006) Mutual regulation of follicle-stimulating hormone signaling and bone morphogenetic protein system in human granulosa cells. Biol Reprod 74:1073-1082.

24. Eppig JJ (2001) Oocyte control of ovarian follicular development and function in mammals. Reproduction 122:829-838.

25. Matzuk MM, Burns KH, Viveiros MM, Eppig JJ (2002) Intercellular communication in the mammalian ovary: Oocytes carry the conversation. Science (Washington D C) 296:2178-2180.

26. Otsuka F, Moore RK, Wang X, Sharma S, Miyoshi T, Shimasaki S (2005) Essential role of the oocyte in estrogen amplification of follicle-stimulating hormone signaling in granulosa cells. Endocrinology 146:3362-3367.

27. Galloway SM, McNatty KP, Cambridge LM, Laitinen MP, Juengel JL, Jokiranta TS, McLaren RJ, Luiro K, Dodds KG, Montgomery GW, Beattie AE, Davis GH, Ritvos O (2000) Mutations in an oocyte-derived growth factor gene (BMP15) cause increased ovulation rate and infertility in a dosage-sensitive manner. Nat Genet 25:279-283.

28. Driancourt MA, Reynaud K, Cortvrindt R, Smitz J (2000) Roles of KIT and KIT LIGAND in ovarian function. Rev Reprod 5:143-152.

29. Moore RK, Otsuka F, Shimasaki S (2003) Molecular basis of bone morphogenetic protein-15 signaling in granulosa cells. J Biol Chem 278:304-310.

30. Wilson T, Wu X-Y, Juengel JL, Ross IK, Lumsden JM, Lord EA, Dodds KG, Walling GA, McEwan JC, O'Connell AR, McNatty KP, Montgomery GW (2001) Highly prolific Booroola sheep have a mutation in the intracellular kinase domain of bone morphogenetic protein IB receptor (ALK-6) that is expressed in both oocytes and granulosa cells. Biol Reprod 64:1225-1235.

31. Mulsant P, Lecerf F, Fabre S, Schibler L, Monget P, Lanneluc I, Pisselet C, Riquet J, Monniaux D, Callebaut I, Cribiu E, Thimonier J, Teyssier J, Bodin L, Cognie Y, Chitour N, Elsen JM (2001) Mutation in bone morphogenetic protein receptor-IB is associated with increased ovulation rate in Booroola Merino ewes. Proc Natl Acad Sci U S A 98:5104-5109.

32. Souza CJH, MacDougall C, Campbell BK, McNeilly AS, Baird DT (2001) The Booroola (FecB) phenotype is associated with a mutation in the bone morphogenetic receptor type $1 \mathrm{~B}$ (BMPR1B) gene. J Endocrinol 169:R1-R6.

33. McNatty KP, Kieboom LE, McDiarmid J, Heath DA, Lun S (1986) Adenosine cyclic 3',5'-monophosphate and steroid production by small ovarian follicles from Booroola ewes with and without a fecundity gene. $J$
Reprod Fertil 76:471-480.

34. Hanrahan JP, Gregan SM, Mulsant P, Mullen M, Davis GH, Powell R, Galloway SM (2004) Mutations in the genes for oocyte-derived growth factors GDF9 and BMP15 are associated with both increased ovulation rate and sterility in Cambridge and Belclare sheep (Ovis aries). Biol Reprod 70:900-909.

35. Moore RK, Shimasaki S (2005) Molecular biology and physiological role of the oocyte factor, BMP-15. Mol Cell Endocrinol 234:67-73.

36. Liao WX, Moore RK, Otsuka F, Shimasaki S (2003) Effect of intracellular interactions on the processing and secretion of bone morphogenetic protein-15 (BMP15 ) and growth and differentiation factor-9. Implication of the aberrant ovarian phenotype of BMP-15 mutant sheep. J Biol Chem 278:3713-3719.

37. Liao WX, Moore RK, Shimasaki S (2004) Functional and molecular characterization of naturally occurring mutations in the oocyte-secreted factors bone morphogenetic protein-15 and growth and differentiation factor-9. J Biol Chem 279:17391-17396.

38. Moore RK, Erickson GF, Shimasaki S (2004) Are BMP15 and GDF-9 primary determinants of ovulation quota in mammals? Trends Endocrinol Metab 15:356-361.

39. Di Pasquale E, Beck-Peccoz P, Persani L (2004) Hypergonadotropic ovarian failure associated with an inherited mutation of human bone morphogenetic protein-15 (BMP15) gene. Am J Hum Genet 75:106-111.

40. Di Pasquale E, Rossetti R, Marozzi A, Bodega B, Borgato S, Cavallo L, Einaudi S, Radetti G, Russo G, Sacco M, Wasniewska M, Cole T, Beck-Peccoz P, Nelson LM, Persani L (2006) Identification of new variants of human BMP15 gene in a large cohort of women with premature ovarian failure. J Clin Endocrinol Metab 91:1976-1979.

41. Dixit H, Rao LK, Padmalatha VV, Kanakavalli M, Deenadayal M, Gupta N, Chakrabarty B, Singh L (2006) Missense mutations in the BMP15 gene are associated with ovarian failure. Hum Genet 119:408-415.

42. Laissue P, Christin-Maitre S, Touraine P, Kuttenn F, Ritvos O, Aittomaki K, Bourcigaux N, Jacquesson L, Bouchard P, Frydman R, Dewailly D, Reyss AC, Jeffery L, Bachelot A, Massin N, Fellous M, Veitia RA (2006) Mutations and sequence variants in GDF9 and BMP15 in patients with premature ovarian failure. Eur $J$ Endocrinol 154:739-744.

43. McMahon HE, Sharma S, Shimasaki S (2008) Phosphorylation of bone morphogenetic protein-15 and growth and differentiation factor-9 plays a critical role in determining agonistic or antagonistic functions. Endocrinology 149:812-817.

44. Scully KM, Rosenfeld MG (2002) Pituitary development: regulatory codes in mammalian organogenesis. Science 295:2231-2235.

45. Dasen JS, O'Connell SM, Flynn SE, Treier M, 
Gleiberman AS, Szeto DP, Hooshmand F, Aggarwal AK, Rosenfeld MG (1999) Reciprocal interactions of Pit1 and GATA2 mediate signaling gradient-induced determination of pituitary cell types. Cell 97:587-598.

46. Huang H-J, Wu JC, Su P, Zhirnov O, Miller WL (2001) A novel role for bone morphogenetic proteins in the synthesis of follicle-stimulating hormone. Endocrinology 142:2275-2283.

47. Fitzpatrick SL, Sindoni DM, Shughrue PJ, Lane MV, Merchenthaler IJ, Frail DE (1998) Expression of growth differentiation factor-9 messenger ribonucleic acid in ovarian and nonovarian rodent and human tissues. Endocrinology 139:2571-2578.

48. Eckery DC, Whale LJ, Lawrence SB, Wylde KA, McNatty KP, Juengel JL (2002) Expression of mRNA encoding growth differentiation factor 9 and bone morphogenetic protein 15 during follicular formation and growth in a marsupial, the brushtail possum (Trichosurus vulpecula). Mol Cell Endocrinol 192:115-126.

49. Cameron VA, Nishimura E, Mathews LS, Lewis KA, Sawchenko PE, Vale WW (1994) Hybridization histochemical localization of activin receptor subtypes in rat brain, pituitary, ovary, and testis. Endocrinology 134:799-808.

50. Takeda M, Otsuka F, Suzuki J, Kishida M, Ogura T, Tamiya T, Makino H (2003) Involvement of activin/ BMP system in development of human pituitary gonadotropinomas and nonfunctioning adenomas. Biochem Biophys Res Commun 306:812-818.

51. Takeda M, Otsuka F, Otani H, Inagaki K, Miyoshi T, Suzuki J, Mimura Y, Ogura T, Makino H (2007) Effects of peroxisome proliferator-activated receptor activation on gonadotropin transcription and cell mitosis induced by bone morphogenetic proteins in mouse gonadotrope LßT2 cells. J Endocrinol 194:87-99.

52. Paez-Pereda M, Giacomini D, Refojo D, Nagashima AC, Hopfner U, Grubler Y, Chervin A, Goldberg V, Goya R, Hentges ST, Low MJ, Holsboer F, Stalla GK, Arzt E (2003) Involvement of bone morphogenetic protein 4 (BMP-4) in pituitary prolactinoma pathogenesis through a Smad/estrogen receptor crosstalk. Proc Natl Acad Sci U S A 100:1034-1039.

53. Giacomini D, Paez-Pereda M, Stalla J, Stalla GK, Arzt E (2009) Molecular interaction of BMP-4, TGF-beta, and estrogens in lactotrophs: impact on the PRL promoter. Mol Endocrinol 23:1102-1114.

54. Miyoshi T, Otsuka F, Otani H, Inagaki K, Goto J, Yamashita M, Ogura T, Iwasaki Y, Makino H (2008) Involvement of bone morphogenetic protein-4 in $\mathrm{GH}$ regulation by octreotide and bromocriptine in rat pituitary GH3 cells. J Endocrinol 197:159-169.

55. Giacomini D, Paez-Pereda M, Theodoropoulou M, Labeur M, Refojo D, Gerez J, Chervin A, Berner S, Losa M, Buchfelder M, Renner U, Stalla GK, Arzt E (2006) Bone morphogenetic protein-4 inhibits corti- cotroph tumor cells: involvement in the retinoic acid inhibitory action. Endocrinology 147:247-256.

56. Petersen SL, Ottem EN, Carpenter CD (2003) Direct and indirect regulation of gonadotropin-releasing hormone neurons by estradiol. Biol Reprod 69:1771-1778.

57. Herbison AE (1998) Multimodal influence of estrogen upon gonadotropin-releasing hormone neurons. Endocr Rev 19:302-330.

58. Herbison AE, Pape JR (2001) New evidence for estrogen receptors in gonadotropin-releasing hormone neurons. Front Neuroendocrinol 22:292-308.

59. Liposits Z, Merchenthaler I, Wetsel WC, Reid JJ, Mellon PL, Weiner RI, Negro-Vilar A (1991) Morphological characterization of immortalized hypothalamic neurons synthesizing luteinizing hormone-releasing hormone. Endocrinology 129:1575-1583.

60. Wetsel WC, Mellon PL, Weiner RI, Negro-Vilar A (1991) Metabolism of pro-luteinizing hormone-releasing hormone in immortalized hypothalamic neurons. Endocrinology 129:1584-1595.

61. Otani H, Otsuka F, Takeda M, Mukai T, Terasaka T, Miyoshi T, Inagaki K, Suzuki J, Ogura T, Lawson MA, Makino H (2009) Regulation of GNRH production by estrogen and bone morphogenetic proteins in GT1-7 hypothalamic cells. $J$ Endocrinol 203:87-97.

62. Foster RH, MacFarlane CH, Bustamante MO (1997) Recent progress in understanding aldosterone secretion. Gen Pharmacol 28:647-651.

63. Lumbers ER (1999) Angiotensin and aldosterone. Regul Pept 80:91-100.

64. Ehrhart-Bornstein M, Hinson JP, Bornstein SR, Scherbaum WA, Vinson GP (1998) Intraadrenal interactions in the regulation of adrenocortical steroidogenesis. Endocr Rev 19:101-143.

65. Suzuki J, Otsuka F, Inagaki K, Takeda M, Ogura T, Makino H (2004) Novel action of activin and bone morphogenetic protein in regulating aldosterone production by human adrenocortical cells. Endocrinology 145:639-649.

66. Inagaki K, Otsuka F, Suzuki J, Otani H, Takeda M, Kano Y, Miyoshi T, Yamashita M, Ogura T, Makino H (2007) Regulatory expression of bone morphogenetic protein- 6 system in aldosterone production by human adrenocortical cells. Regul Pept 138:133-140.

67. Inagaki K, Otsuka F, Suzuki J, Kano Y, Takeda M, Miyoshi T, Otani H, Mimura Y, Ogura T, Makino H (2006) Involvement of bone morphogenetic protein-6 in differential regulation of aldosterone production by angiotensin II and potassium in human adrenocortical cells. Endocrinology 147:2681-2689.

68. Staessen J, Lijnen P, Fagard R, Verschueren LJ, Amery A (1981) Rise in plasma concentration of aldosterone during long-term angiotensin II suppression. $J$ Endocrinol 91:457-465.

69. Lijnen P, Staessen J, Fagard R, Amery A (1982) Increase 
in plasma aldosterone during prolonged captopril treatment. Am J Cardiol 49:1561-1563.

70. Naruse M, Tanabe A, Sato A, Takagi S, Tsuchiya K, Imaki T, Takano K (2002) Aldosterone breakthrough during angiotensin II receptor antagonist therapy in stroke-prone spontaneously hypertensive rats. Hypertension 40:28-33.

71. Sato A, Saruta T (2001) Aldosterone escape during angiotensin-converting enzyme inhibitor therapy in essential hypertensive patients with left ventricular hypertrophy. J Int Med Res 29:13-21.

72. Sato A, Hayashi K, Naruse M, Saruta T (2003) Effectiveness of aldosterone blockade in patients with diabetic nephropathy. Hypertension 41:64-68.

73. Sato A, Saruta T (2003) Aldosterone breakthrough during angiotensin-converting enzyme inhibitor therapy. Am J Hypertens 16:781-788.

74. Otani H, Otsuka F, Inagaki K, Suzuki J, Miyoshi T, Kano Y, Goto J, Ogura T, Makino H (2008) Aldosterone breakthrough caused by chronic blockage of angiotensin II type 1 receptors in human adrenocortical cells: Possible involvement of bone morphogenetic protein-6 actions. Endocrinology 149:2816-2825.

75. Bornstein SR, Gonzalez-Hernandez JA, EhrhartBornstein M, Adler G, Scherbaum WA (1994) Intimate contact of chromaffin and cortical cells within the human adrenal gland forms the cellular basis for important intraadrenal interactions. J Clin Endocrinol Metab 78:225-232.

76. Schinner S, Bornstein SR (2005) Cortical-chromaffin cell interactions in the adrenal gland. Endocr Pathol 16:91-98

77. Wurtman RJ, Pohorecky LA, Baliga BS (1972) Adrenocortical control of the biosynthesis of epinephrine and proteins in the adrenal medulla. Pharmacol Rev 24:411-426.

78. Kano Y, Otsuka F, Takeda M, Suzuki J, Inagaki K, Miyoshi T, Miyamoto M, Otani H, Ogura T, Makino H (2005) Regulatory roles of bone morphogenetic proteins and glucocorticoids in catecholamine production by rat pheochromocytoma cells. Endocrinology 146:5332-5340.

79. Mehler MF, Mabie PC, Zhang D, Kessler JA (1997) Bone morphogenetic proteins in the nervous system. Trends Neurosci 20:309-317.

80. Reissmann E, Ernsberger U, Francis-West PH, Rueger D, Brickell PM, Rohrer H (1996) Involvement of bone morphogenetic protein-4 and bone morphogenetic protein-7 in the differentiation of the adrenergic phenotype in developing sympathetic neurons. Development 122:2079-2088.

81. Varley JE, Wehby RG, Rueger DC, Maxwell GD (1995) Number of adrenergic and islet-1 immunoreactive cells is increased in avian trunk neural crest cultures in the presence of human recombinant osteogenic protein-1. Dev Dyn 203:434-447.
82. Varley JE, Maxwell GD (1996) BMP-2 and BMP-4, but not BMP-6, increase the number of adrenergic cells which develop in quail trunk neural crest cultures. Exp Neurol 140:84-94.

83. Goto J, Otsuka F, Yamashita M, Suzuki J, Otani H, Takahashi H, Miyoshi T, Mimura Y, Ogura T, Makino H (2009) Enhancement of aldosterone-induced catecholamine production by bone morphogenetic protein-4 through activating Rho and SAPK/JNK pathway in adrenomedullar cells. Am J Physiol Endocrinol Metab 296:E904-916.

84. Vassart G, Dumont JE (1992) The thyrotropin receptor and the regulation of thyrocyte function and growth. Endocr Rev 13:596-611.

85. Farid NR, Shi Y, Zou M (1994) Molecular basis of thyroid cancer. Endocr Rev 15:202-232.

86. Franzen A, Piek E, Westermark B, ten Dijke P, Heldin NE (1999) Expression of transforming growth factorbeta1, activin A, and their receptors in thyroid follicle cells: negative regulation of thyrocyte growth and function. Endocrinology 140:4300-4310.

87. Suzuki J, Otsuka F, Takeda M, Inagaki K, Miyoshi T, Mimura Y, Ogura T, Doihara H, Makino H (2005) Functional roles of the bone morphogenetic protein system in thyrotropin signaling in porcine thyroid cells. Biochem Biophys Res Commun 327:1124-1130.

88. Franzen A, Heldin NE (2001) BMP-7-induced cell cycle arrest of anaplastic thyroid carcinoma cells via p21(CIP1) and p27(KIP1). Biochem Biophys Res Commun 285:773-781.

89. Wilkins MR, Gibbs JS, Shovlin CL (2000) A gene for primary pulmonary hypertension. Lancet 356:12071208.

90. Nichols WC, Koller DL, Slovis B, Foroud T, Terry VH, Arnold ND, Siemieniak DR, Wheeler L, Phillips JAr, Newman JH, Conneally PM, Ginsburg D, Loyd JE (1997) Localization of the gene for familial primary pulmonary hypertension to chromosome 2q31-32. Nat Genet 15:277-280.

91. Deng Z, Morse JH, Slager SL, Cuervo N, Moore KJ, Venetos G, Kalachikov S, Cayanis E, Fischer SG, Barst RJ, Hodge SE, Knowles JA (2000) Familial primary pulmonary hypertension (gene PPH1) is caused by mutations in the bone morphogenetic protein receptor-II gene. Am J Hum Genet 67:737-744.

92. Lane KB, Machado RD, Pauciulo MW, Thomson JR, Phillips JA, 3rd, Loyd JE, Nichols WC, Trembath RC (2000) Heterozygous germline mutations in BMPR2, encoding a TGF-beta receptor, cause familial primary pulmonary hypertension. The International $\mathrm{PPH}$ Consortium. Nat Genet 26:81-84.

93. Thomson JR, Machado RD, Pauciulo MW, Morgan NV, Humbert M, Elliott GC, Ward K, Yacoub M, Mikhail G, Rogers P, Newman J, Wheeler L, Higenbottam T, Gibbs JS, Egan J, Crozier A, Peacock A, 
Allcock R, Corris P, Loyd JE, Trembath RC, Nichols WC (2000) Sporadic primary pulmonary hypertension is associated with germline mutations of the gene encoding BMPR-II, a receptor member of the TGF-beta family. J Med Genet 37:741-745.

94. Morrell NW, Yang X, Upton PD, Jourdan KB, Morgan N, Sheares KK, Trembath RC (2001) Altered growth responses of pulmonary artery smooth muscle cells from patients with primary pulmonary hypertension to transforming growth factor-beta(1) and bone morphogenetic proteins. Circulation 104:790-795.

95. Rudarakanchana N, Flanagan JA, Chen H, Upton PD, Machado R, Patel D, Trembath RC, Morrell NW (2002) Functional analysis of bone morphogenetic protein type II receptor mutations underlying primary pulmonary hypertension. Hum Mol Genet 11:1517-1525.

96. Takeda M, Otsuka F, Nakamura K, Inagaki K, Suzuki J, Miura D, Fujio H, Matsubara H, Date H, Ohe T, Makino H (2004) Characterization of the bone morphogenetic protein (BMP) system in human pulmonary arterial smooth muscle cells isolated from a sporadic case of primary pulmonary hypertension: roles of BMP type IB receptor (activin receptor-like kinase-6) in the mitotic action. Endocrinology 145:4344-4354.

97. Wang SN, Lapage J, Hirschberg R (2001) Loss of tubular bone morphogenetic protein-7 in diabetic nephropathy. J Am Soc Nephrol 12:2392-2399.

98. Hruska KA, Guo G, Wozniak M, Martin D, Miller S, Liapis H, Loveday K, Klahr S, Sampath TK, Morrissey J (2000) Osteogenic protein-1 prevents renal fibrogenesis associated with ureteral obstruction. Am J Physiol Renal Physiol 279:F130-143.

99. Martinez G, Bertram JF (2003) Organisation of bone morphogenetic proteins in renal development. Nephron Exp Nephrol 93:e18-22.

100. Morrissey J, Hruska K, Guo G, Wang S, Chen Q, Klahr $\mathrm{S}$ (2002) Bone morphogenetic protein-7 improves renal fibrosis and accelerates the return of renal function. $J$ Am Soc Nephrol 13 Suppl 1:S14-21

101. Wang S, Chen Q, Simon TC, Strebeck F, Chaudhary L, Morrissey J, Liapis H, Klahr S, Hruska KA (2003) Bone morphogenic protein-7 (BMP-7), a novel therapy for diabetic nephropathy. Kidney Int 63:2037-2049.

102. Wang S, Hirschberg R (2003) BMP7 antagonizes TGFbeta -dependent fibrogenesis in mesangial cells. Am J Physiol Renal Physiol 284:F1006-1013.

103. Otani H, Otsuka F, Inagaki K, Takeda M, Miyoshi T, Suzuki J, Mukai T, Ogura T, Makino H (2007) Antagonistic effects of bone morphogenetic protein-4 and -7 on renal mesangial cell proliferation induced by aldosterone through MAPK activation. Am J Physiol Renal Physiol 292:F1513-1525.

104. Foster PA (2008) Steroid metabolism in breast cancer. Minerva Endocrinol 33:27-37.

105. Sasano H, Suzuki T, Nakata T, Moriya T (2006) New development in intracrinology of breast carcinoma. Breast Cancer 13:129-136.

106. Raida M, Clement JH, Ameri K, Han C, Leek RD, Harris AL (2005) Expression of bone morphogenetic protein 2 in breast cancer cells inhibits hypoxic cell death. Int J Oncol 26:1465-1470.

107. Clement JH, Sanger J, Hoffken K (1999) Expression of bone morphogenetic protein 6 in normal mammary tissue and breast cancer cell lines and its regulation by epidermal growth factor. Int J Cancer 80:250-256.

108. Schwalbe M, Sanger J, Eggers R, Naumann A, Schmidt A, Hoffken K, Clement JH (2003) Differential expression and regulation of bone morphogenetic protein 7 in breast cancer. Int J Oncol 23:89-95.

109. Pouliot F, Labrie C (2002) Role of Smad1 and Smad4 proteins in the induction of p21WAF1,Cip1 during bone morphogenetic protein-induced growth arrest in human breast cancer cells. J Endocrinol 172:187-198.

110. Clement JH, Raida M, Sanger J, Bicknell R, Liu J, Naumann A, Geyer A, Waldau A, Hortschansky P, Schmidt A, Hoffken K, Wolft S, Harris AL (2005) Bone morphogenetic protein 2 (BMP-2) induces in vitro invasion and in vivo hormone independent growth of breast carcinoma cells. Int J Oncol 27:401-407.

111. Helms MW, Packeisen J, August C, Schittek B, Boecker W, Brandt BH, Buerger H (2005) First evidence supporting a potential role for the BMP/SMAD pathway in the progression of oestrogen receptor-positive breast cancer. J Pathol 206:366-376.

112. Takahashi M, Otsuka F, Miyoshi T, Otani H, Goto J, Yamashita M, Ogura T, Makino H, Doihara H (2008) Bone morphogenetic protein 6 (BMP6) and BMP7 inhibit estrogen-induced proliferation of breast cancer cells by suppressing p38 mitogen-activated protein kinase activation. $J$ Endocrinol 199:445-455.

113. Mukai T, Otsuka F, Otani H, Yamashita M, Takasugi K, Inagaki K, Yamamura M, Makino H (2007) TNFalpha inhibits BMP-induced osteoblast differentiation through activating SAPK/JNK signaling. Biochem Biophys Res Commun 356:1004-1010.

114. Yamashita M, Otsuka F, Mukai T, Otani H, Inagaki K, Miyoshi T, Goto J, Yamamura M, Makino H (2008) Simvastatin antagonizes tumor necrosis factor-alpha inhibition of bone morphogenetic proteins-2-induced osteoblast differentiation by regulating Smad signaling and Ras/Rho-mitogen-activated protein kinase pathway. J Endocrinol 196:601-613.

115. Hogan BLM (1996) Bone morphogenetic proteins: multifunctional regulators of vertebrate development. Genes Dev 10:1580-1594.

116. Lyons KM, Pelton RW, Hogan BL (1990) Organogenesis and pattern formation in the mouse: RNA distribution patterns suggest a role for bone morphogenetic protein2A (BMP-2A). Development 109:833-844. 